\title{
DŽIHAD KAO GLOBALNI TERORIZAM
}

\author{
Hatidža Beriša \\ Univerzitet odbrane u Beogradu, Škola nacionalne odbrane \\ Milenko Dželetović \\ Univerzitet u Beogradu, Fakultet bezbednosti \\ Igor Barišić \\ Univerzitet odbrane u Beogradu, Škola nacionalne odbrane \\ Ivan Rančić \\ Vojska Srbije RV i PVO
}

Gobalizacija kao univerzalni posthladnoratovski geopolitički proces
nameće nove standarde i principe međunarodnih odnosa u kojima se sve nacionalne, socijalne, etničke, političke, kulturne, konfensionalne i druge specifičnosti zemalja i regiona potiskuje, marginalizuju, i potčinjavaju praksi ograničenog suvereniteta. Takav proces nailazi na otpore zemalja političkih protivnika, verskih i nacionalnih grupa i brojnih slobodoumnih građana koji ga doživljavaju kao ekspanziju neokolonijalizma.

Terorizam se u pojedinim, islamskim zemljama i neguje ne samo kao vrhunsko nacionalno strategijsko opredeljenje, već i kao kulturno - verski i kao pitanje društvenog morala. Zloupotrebljavajući islamsku veru, na toj platformi gradi i dobija podršku jednog broja fanatičnih vernika, islamističkih grupa i organizacija koje vode borbu za stvaranje islamske države na zemaljskoj kugli programiranjem „džihada“

Cilj rada je da se sagleda kako je „džihad“ zloupotrebljen u svrhu globalnog terorizma, da se analizira geneza terorizma, njegov nastanak i razvoj sa akcentom na religijski terorizam.

Ključne reči: globalni džihad, globalizacija, islamske države, religija, terorizam

„Ubi jednog da bi uplašio hiljade"

Stara kineska poslovica

Uvod

7 a navedenu kinesku poslovicu, može se reći da predstavlja osnovni moto, kako prošlih tako i savremenih terorističkih organizacija i da je danas aktuelna koliko i u vremenu kada je izrečena. Cilj je ostao isti (izazivanje straha), nasilje je metod, samo su se sredstva kojim se teži ostvarivanju tog cilj promenila. Promeni tih sredstava značajno je doprineo „fenomen” globalizacije.

Globalizacija kao društveno-istorijski proces koji obuhvata skoro sva područja individualne, grupne i kolektivne ljudske civilizacije, nije vezana samo za politiku, već i za nauku ekonomiju, tehnologiju, kulturu, religiju, zabavu, sport i medije. U tom kontekstu najznačajnije dimenzije globalizacije su: ekonomska, politička, ideološko-kulturna, vojna, geostrateška i ekološka dimenzija. 
Reč je o realnom planetarnom procesu sve gušće mreže povezanosti i međuzavisnosti pojedinačnih društva i stvaranju jedinstvenog „svetskog sistema”, koji izrasta na izumima nove tehničko-tehnološke revolucije i brzom ritmu stvaranja globalne ekonomije: na talasima kulturno-informatičke revolucije (stvaranje kosmopolitske kulture, homogenizacija ukusa, obrazaca ishrane, odevanja i životnih stilova), i na mreži nadnacionalnih, regionalnih i svetskih institucija (savet bezbednosti OUN, Međunarodni monetarni fond, Međunarodna banka za obnovu i razvoj, Svetska trgovinska organizacija, G-8, Evropska unija, i druge), kao značajnim polugama i mehanizmima globalnog upravljanja.

U mnoštvo načina pružanja otpora globalizmu, osim širokog spektra legalnih metoda, nalazi se i savremeni (globalni) terorizam, kao specifičan fenomen savremenog doba. Po organizacionom, kadrovskom, naučno-tehnološkom, finansijskom i svakom drugom potencijalno prednjači terorizam islamističkih grupa i organizacija.

Terorizam se u pojedinim, islamističkim zemljama neguje ne samo kao vrhunsko nacionalno strategijsko opredeljenje, već i kao kulturno, versko i pitanje društvenog morala. Zloupotrebljavajući islamsku veru, na toj platformi gradi i dobija podršku jednog broja fanatičnih vernika, islamističke grupe i organizacije vode borbu za stvaranje jedinstvene islamske države na zemaljskoj kugli programiranjem „džihada”.

$\mathrm{U}$ mnogim delovima sveta islamski fundamentalisti su odbacili vrednosti zapadno orijentisanih sekularnih država u korist islamskih vrednosti. Pokreti, koji odlikuju snažna nacionalna, verska i autohtona kulturna osećanja, otvoreno iskazuju antizapadna osećanja uperena protiv bivših hrišćanskih kolonijalnih snaga iz Evrope.

Ista antizapadna osećanja nastaju kao posledica nametanja globalne političke, ekonomske, vojne i kulturne dominacije zapada kroz proces globalizacije. Oni su u više navrata glavnim protagonistima globalizacije uputili jasnu poruku koja glasi: „imamo svoju tradiciju, pripadamo drukčijoj civilizaciji, verujemo u druge ideale, razlikujemo se po verskoj pripadnosti i nećemo prozapadnjačenje."

\section{Globalizacija - podsticaj džihada}

Globalizacija $^{1}$ je jedna česta upotrebljavana reč, kojoj se pridaju mnoga različita značenja. Pri tom, i sam termin je veoma neprecizan i može se lako ideologizirati. Reč je o jednom veoma složenom fenomenu, to jest procesu ili kako neki smatraju projektu. Globalizacija je istorijski fenomen koji predstavlja predmet najšireg interesovanja javnosti širom sveta, počev od običnih građana koji žele da shvate šta se događa usled globalizacije, potom političara koji nastoje da ostvare upravljanje promenama i umanje eventualne štete svojim državama zbog nje, do teoretičara koji nastoje da otkriju suštinu, uzroke, nosioce i pokretače globalizacije.

Termin globalizacija se još u kasnim osamdesetim godinama prošlog veka veoma retko koristio, kako u akademskoj literaturi, tako u svakodnevnom govoru. Termin je kako kaže Entoni Gidens (Anthons Giddens), došao niotkuda da bi danas postao ključna tema u razmatranjima savremenih ekonomskih, političkih i drugih zbivanja. Globalizacija je i

\footnotetext{
${ }^{1}$ Engleska reč „global”, potiče od latinske reči „globus”. Od kraja 19. veka, u engleskom jeziku se pridev „globa" koristi da označi "ceo svet", odnosno ono što pokriva ili utiče na ceo svet. Pre toga je ta reč uglavnom označavala sferu (spherical). Globalno predstavlja suprotnost lokalnom, nacionalnom i regionalnom. Imenica je 1961. godine prvi put ušla u Vebsterov rečnik engleskog jezika).
} 
među najneupućenijima prestala biti fenomen koji se dešava negde „vani” i nekom drugom. To je proces koji se odvija upravo "ovde" i koji snažno utiče na intimni i lični aspekt života svakog od nas.

Uprkos činjenici da o globalizaciji postoje brojne monografske studije i gotovo nepregledna literatura sa preko 200.000 internet stranica koje se bave pitanjem globalizacije, ova tema je više poznata nego saznata. Otuda se autentična rasprava o globalizaciji ne može svesti na izlaganje jednog autora, ma kako ono izgledalo uverljivo. ${ }^{3}$

Definicije termina globalizacija ima mnogo, gotovo koliko i teoretičara globalizacije, jer teško da postoje dva autora koja o ovom pojmu identično promišljaju. Te definicije se drastično razlikuju, zavisno prvenstveno (mada ne i jedino!) od teorijske pozicije koju zauzima autor tako da bismo mogli reći da se već iz definicije može naslutiti iz koje škole potiče teoretičar. Doduše, ima i autora koji su pokušali da daju teorijske neutralne „operacionalne" definicije. Ono što još razlikuje autore po pitanju definicija globalizacije, ogleda se u aspektu, dimenziji koja se percipira kao prevashodna i koja je ključna u razmatranju globalizacije. Ukazaćemo na dve definicije globalizacije i to Entoni Gidensa i Dejvida Helda. Etnoni Gidens definiše globalizaciju kao „intenzifikaciju društvenih odnosa na svetskom planu koja povezuje udaljena mesta tako da lokalna zbivanja uobličavaju događaji koji su se odigrali na velikoj udaljenosti". ${ }^{4}$

Za Helda, globalizacija može da bude shvaćena kao širenje, produbljenje i ubrzavanje svetske međuzavisnosti svih aspekata modernog društvenog života. ${ }^{5}$ Kada preciznije definiše globalizaciju, isti autor pod tim pojmom podrazumeva „takvo širenje i produbljivanje društvenih odnosa i institucija u prostoru i vremenu koje čine da se svakodnevne aktivnosti sve više nalaze pod uticajem događaja koji se zbivaju na drugoj strani sveta, a praksa i odluke lokalnih grupa i zajednica mogu da imaju značajan globalni odjek". ${ }^{6}$

Prema mišljenju Miroslava Pečujlića, globalizacija je objektivan planetarni proces stvaranja guste mreže povezanosti, međuzavisnosti sve šireg kruga društva, pri čemu je sve širi krug delatnosti koje postaju transnacionalne, odnosno kojima se ne može upravljati isključivo unutar društvenih granica. ${ }^{7}$ Isti autor smatra da se globalizacija ne svodi samo na proces svestranog povezivanja sveta. Prema njemu, „od presudne je važnosti njena druga dimenzija: njena priroda, karakter globalnog poretka koji nastaje kao plod subjektivnih interesa i strategije, projekta transnacionalne elite moći” ${ }^{8}$

Danas postoje, različita shvatanja globalizacije: od njenog shvatanja kao nužnog istorijskog procesa u razvoju društva, njenog ostvarivanja kao zakonitog procesa u razvoju ljudskog društva (sa ukazivanjem na njene negativne posledice) i njenog shvatanja isključivo kao projekta dominacije Zapada i amerikanizacije sveta koja dovodi do fragmentacije sveta i stvaranja sve dubljeg jaza između svetova, dovodeći do sukoba civilizacija. ${ }^{9}$

\footnotetext{
${ }^{2}$ Gidenes Entoni, Globalizacija shvaćena ozbiljno, Republika, Beograd, 2000, str. 246.

${ }^{3}$ Jovica Trkulja, Aspekti globalizacije, Beogradska otvorena škola, Beograd, 2003, str. 20.

${ }^{4}$ Entoni Gidens: Posledice modernosti, Filip Višnjić, Beograd, 1998, str. 69.

${ }^{5}$ Dejvid Held: Debate o globalizaciji, u V. Vuletić: Globalizacija mit ili stvarnost, str. 48.

${ }^{6}$ Dejvid Held: Demokratija i globalni poredak, Filip Višnjić, Beograd, 1977, str. 33.

${ }^{7}$ Miroslav Pečujlić: Globalizacija dva lika sveta, Guterbergova galaksija, Beograd, 2002, str. 17.

${ }^{8}$ Miroslav Pečujlić: Planetarni kentaur, Nova srpska politička misao, Nova edicija, vol. VII, PO 13-4.

${ }^{9}$ Miroslav Pečujlić: Planetarni kentaur, Nova srpska politička misao, Nova edicija, vol. VII, PO 13-4.
} 
U ovom smislu treba shvatiti i ukazivanje Kofi Anana (bivšeg generalnog sekretara OUN-a), da milioni ljudi u celom svetu doživljavaju globalizaciju ne kao instrument progresa, već kao rušilačku silu, sličnu uraganu i sposobnu da ubije život, rad, porodice. Za mnoge ljude karakteristično je jako osećanje suprotstaviti se tom procesu i ostati spokojan u uslovima nacionalizma, fundamentalizma i drugih „izmova”. ${ }^{10}$

lako postoje shvatanja o negativnim posledicama globalizacije, ne mogu se prenebreći i shvatanja o njenim pozitivnim posledicama na razvoj društva. U ovom smislu je i ukazivanje da je globalizacija „moćan instrumenat rasprostiranja velikih inovacija: informatičke revolucije i superiornijih socijalnih formi (modernog tržišta, kosmopolitičke kulture i demokratije) na vlastito tlo. ${ }^{11} \mathrm{U}$ stvari „Moćne materijalne sile idu ruku pod ruku sa tkanjem duhovne niti stvaranja globalne svetske kulture. Medijska, elektronska revolucija i njeni proizvodi: vesti, filmovi, umetničke serije i muzički hitovi prelaze geografske granice, homogenizuju životne uslove, ukuse i poglede". ${ }^{12}$

U osnovi savremene globalizacije $s$ jedne strane leži jednostavan koncept koji se zasniva na tržišnom sistemu privređivanja i demokratiji zapadnog modela. Lako se može uočiti da je politička globalizacija u funkciji ekonomske globalizacije i geostrateških interesa zapadnih zemalja, jer putem uspostavljanja liberalnih demokratskih režima u bivšim sovjetskim zemljama i zemljama u razvoju, globalne zapadne sile, pre svega SAD, ostvaruju svoje ekonomske i geostrateške interese. ${ }^{13}$ Sa druge strane, činjenica je da nisu svi aspekti postali istovremeno u jednom trenutku istorije ljudskog društva, već su nastajali vremenom, godinama, decenijama, pa čak i vekovima. Uslovno govoreći, mogle bi se uočiti četiri dimenzije: ekološka, vojna, socio-politička i ekonomska. ${ }^{14}$ Važno je napomenuti da su sve gore navedene dimenzije globalizacije veoma povezane i da se sve uzajamno determinišu i utiču jedna na drugu.

Uprkos ogromnom povećanju obima međuzavisnosti i saradnje, vojna sila je veoma značajna u procesu globalizacije. lako su smanjene opasnosti od velikih ratnih sukoba, nije se prestalo s upotrebom sile u međunarodnim odnosima. Postoje čak predviđanja da će vojno-represivna dimenzija globalizacije tokom 21. veka biti još izraženija. Revitalizacija NATO-a i širenje njegovih nadležnosti van teritorija zemalja članica, snažna tendencija planetarnog vojnog interencionizma i težnja SAD za uspostavljanjem i očuvanjem apsolutnog primata na osnovu sopstvene vojne moći, dopunjavaju sliku o ambivalentom karakteru globalnog procesa i neizvesnostima koje donosi. ${ }^{15}$

Nezaobilazni aspekt globalizacije je proces uspostavljanja svetskog vojnog poretka, odnosno, smena bipolarne strukture, unipolarnom strukturom organizovane vojne sile. To je uverenje većeg broja teoretičara globalizacije, među kojima je i Entoni Gidens, koji se smatra jednim od vodećih autoriteta u tumačenju socijalnih pojava savremenog sveta.

\footnotetext{
${ }^{10}$ Danilo Ž. Marković: Globalizacija obrazovanja, Zbornik radova sa naučnog skupa osnovna polazišta obrazovanja, Srpska akademija obrazovanja, Beograd, 2006, str. 8.

${ }^{11}$ Miroslav Pečujlić: Globalizacija dva lika sveta, Guterbergova galaksija, Beograd, 2002, str. 1.

12 Isto, str. 82

${ }^{13}$ Stanislav Stojanović: Globalizacija i bezbednosne perspektive sistema, VIZ, Beograd, 2009, str. 65-89.

${ }^{14}$ Hatidža Beriša, i autori: „Međusobni uticaj procesa globalizacije i terorizam”, Međunarodni naučni skup: Određenje, organizacija i djelatnost subjekata nacionalnih sistema bezbednosti, FBZ, Univerzitet sinergija, Banja Luka, 26.10.2014, str. 141-145.

${ }^{15}$ Stanislav Stojanović: Globalizacija i bezbednosne perspektive sistema, VIZ, Beograd, 2009, str. 18.
} 
Prema njemu, uspostavljanje svetskog vojnog poretka jedan je od ključnih fenomena procesa globalizacije. Za Naja, vojna globalizacija je mreža međuzavisnosti u kojima se primenjuju sila ili pretnja silom, ${ }^{16}$ pri čemu je i globalizacija terorističke mreže takođe novi oblik vojne globalizacije. ${ }^{17}$

$\mathrm{Na}$ vojnostratešku dimenziju procesa globalizacije ukazuju i mnogi naši teoretičari globalizacije. Trkulja naglašava da „smena bipolarne strukture unipolarnom strukturom organizovanja fizičke sile sa tendencijom stvaranja fronta neprikosnovane i neporecive vojne hegemonije dominantnih sila sveta, te novih načina legitimisanja militarizacije", čini dominantan aspekat međunarodnih odnosa koji se kreiraju u procesu globalizacije.

Preispitivanjem međunarodne politike posle okončanja hladnog rata dolazi se do zaključka da je neodrživo svojevremeno opšteprihvaćeno mišljenje da će svet postati racionalniji i bezbedniji. Pokazalo se da se nisu obistinile tvrdnje onih koji su globalizaciju najavljivali kao formulu za obezbeđenje harmonije ekonomskog i političkog razvoja globalnog društva, kao i progresa, mira i međunarodnih odnosa, zasnovanih na saradnji. Danas je sasvim jasno, kako zaključuje Hantington da je „paradigma jednog harmoničnog sveta isuviše daleko od stvarnosti..."18

Prihvaćeno je mišljenje da globalizacija kreira ambijent u kome dominantni rizici po bezbednost poprimaju nevojni karakter. Naime, intenziviranje ekonomskih tokova, sistema komunikacija i transporta izaziva transnacionalizaciju negativnih efekata tih procesa, što doprinosi porastu međunarodnog organizovanog kriminala, međunarodnog terorizma, trgovine drogom i oružjem, etničkih i religioznih konflikata i ekološke zagađenosti. ${ }^{19}$

Globalizacija snažno postiče kulturnu homogenizaciju i uspostavljanje kosmopolitskog identiteta. Pod uticajem modernih komunikacija šire se socijalne, političke i ekonomske aktivnosti i postaju dostupni socijalni i fizički miljei sa kojima se društveni kolektiviteti i pojedinci nikada nisu sretali. Uporedo s tim procesima, došlo je do prave eksplozije pluralizma i jačanje religijskih etničkih identiteta tako da globalizacija, kao proces afirmacije univerzalne kulture centra, izaziva sve veći broj perifernih identiteta. ${ }^{20}$

Razorni radikalizam tržišnih institucija i ekstremna univerzalistička pretenzija aktera globalizacije, zasnovana na moći medija, kompjuterske industrije, obrazovanja, nauke i umetnosti koji dobijaju industrijski karakter, usmerena je na menjanje vrednosne matice i prikazivanje zapadnog sistema vrednosti kao jedino mogućeg i najboljeg, što neminovno dovodi do odbacivanja drugih vrednosnih modela. Posledica toga je prava erupcija različitih formi tradicionalizma, lokalizma i konflikata, antiamerikanizma i protiv zapadnog raspoloženja. Smatrajući da su takve posledice nužne, Volerstin ih objašnjava na sledeći način: „Kada se univerzalizmi koriste za uništavanje i tlačenje, ljudi nalaze utočište u partikularizmima. Oni predstavljaju očiglednu odbranu i to uglavnom veoma nužnu odbranu".

\footnotetext{
${ }^{16}$ Džozef Naj, Paradoks, američka moć, BMG, Beograd, 2004, str. 124.

${ }^{17}$ Isto, str. 126.

${ }^{18}$ Semjuel Hantington: Sukob civilizacije i preoblikovanje svetskog poretka, CID, Podgorica, 1999, str. 33.

${ }^{19} \mathrm{O}$ teorijama sukoba - konflikata videti kod: Radomir Milašinović, Srđan Milašinović, Uvod u teoriji konflikata, FB, Beograd, 2004.

${ }^{20}$ Dragan I. Bjelić: Globalizacija i otpori, Nova srpska politička misao, Nova edicija, VII, BR 3-4.

${ }^{21}$ I. Volerstin: Opadanje amaričke moći, Podgorica, 2004. str. 12.
} 
Proces otpora dominantnim tendencijama globalizacije praćen je i snažnim oživljavanjem religije širom sveta, što još više pojačava kulturne razlike. U pokušaju da sociološki objasni takve tendencije, Hantington naglašava da je oživljavanje religije širom sveta „reakcija protiv ledenog egoizma i izraz je dubokog stremljenja vrednostima solidarnosti i međusobnog pomaganja. Verske zajednice odgovor su na široke potrebe koje državna birokratija i tržište ostavljaju nezadovoljnim. Muslimani se masovno okreću islamu kao izvoru nade, identiteta i moći, internacionalne solidarnosti islamskih država, drugačijeg načina života, jednoj vrsti socijalne države u okviru sekularne države. ${ }^{22}$

$U$ vezi s tim, faktor kulturnog identiteta posebno je značajan kad je reč o orijentalnim religijama u kojima je akcenat dat na kolektivizmu. U okviru postojećih globalnih sukoba u kulturi, osobenost tih religija može da dovede do uspostavljanja najpopulističkijih koalicija u svetu. Islamski fundamentalizam, u tom kontekstu, ogromna je pretnja po globalni mir i bezbednost, ali je u suštini opasan i katastrofalan prvenstveno za sam arapski svet.

Globalizacija bi morala biti po svojoj prirodi pluralistička, a ne u znaku monizma, nametanja jednog tipa društva, vrednosne svesti i kulture. ${ }^{23}$ Budući da se prinudno nametanje novog modela sve snažnije doživljava kao nešto što nameće Zapad, politički islam, u raznim oblicima, postaje sve privlačniji za milione muslimana širom Bliskog istoka i severne Afrike, a neke radikalne varijante predstavljaju snažne razloge za socijalne i političke podele.

Kao proces u kojem učestvuju neravnopravni učesnici, globalizacija umnožava nejednakost, nesigurnost, nezadovoljstvo i frustracije, a takvo stanje pogoduje nastanku ekstremizma. Religije, zemlje i grupe koje se osećaju zapostavljenim suočavaju se sa sve dubljom ekonomskom stagnacijom, političkom nestabilnošću i kulturnim otuđenjem. Sve to doprinosi jačanju političkog, etničkog i verskog ekstremizma, uporedo sa nasiljem koji prati države sa slabim sistemom uprave, etničkim, kulturnim i verskim tenzijama, slabom privredom i propusnom granicom. Predviđa se da će do 2020. godine terorizam još više ojačati, pri čemu će neke formacije nadmašiti snage „Al Kaide”. Tendencija ka stvaranju raznovrsnijih transnacionalnih terorističkih mreža može da dovede do formiranja međunarodnih terorističkih koalicija s raznovrsnim protiv zapadnim ciljevima i pristupom oružja za masovno uništenje. Procenjuje se da će antiamerički terorizam uglavnom biti izazvan etničkim, verskim i kulturnim problemima, a teroristi će, verovatno, biti stacionirani na Bliskom istoku i jugozapadu Azije. ${ }^{24}$

Kao moguće rešenje navedenih protivrečnosti usled globalizacije može se uzeti mišljenje Čarlsa Nendija koji nudi teoriju kulturnog sklada čija je suština poštovanje različitosti. On naglašava da se, zbog razlika u sredini, nacionalnoj kulturi, i profesionalnoj sredini u samim organizacijama, način na koji se radi u jednoj zemlji mogu razlikovati od načina na koji se radi u drugoj zemlji. Preslikavanjem tuđih rešenja i organizovanjem po „povremenom” modelu nekih uspešnih, što podrazumeva i dobro zaštićenih organizacija, može se nesvesno upasti u zamku kulturnih ograničenja, zbog čega će njihova promena biti ograničena ili čak nemoguća, i umesto očekivane koristi mogu proizvesti štetu.

\footnotetext{
${ }^{22}$ Miroslav Pečujlić: Globalizacija dva lika sveta, Gutenbergova galaksija, Beograd, 2002, str. 141.

${ }^{23}$ Zoran Vidojević: Kuda vodi globalizacija, Filip Višnjić, Beograd, 2005, str. 53.

${ }^{24} \mathrm{Global}$ trends 2015, http://www.cia.gov/news-information/press-releases-statements/press-release-archive2000/12182000 html, 21.01.2018
} 


\section{Terorizam - izvorište džihada}

Terorizam, kao veliki problem savremenog društva, postao je pojava, pojam, misao i termin koji je ušao u svakodnevni život savremenog čoveka. Uporedno sa razvojem i napretkom čovečanstva u tehničkom, materijalnom i kulturnom pogledu, razvija se i terorizam i samo još bržim tempom. Terorizam se stalno menja po formi, sadržini, tipovima i oblicima organizovanja i načinima delovanja. Eksplozija terorizma poslednjih godina, uzrokuje strašan porast broja žrtava, materijalnih razaranja, kao i katastrofalne posledice koje on ostavlja za sobom u ruši temelje savremene civilizacije. Terorizam je, dakle, postao najaktuelniji oblik nasilja koji po ambicijama prevazilazi sve druge oblike političkog nasilja, bezumlja, izopačenosti i mržnje.

Proces globalizacije i uspostavljanja „novog svetskog poretka” doveli su do pojačanog dejstva asimetrije, što je prvenstveno ispoljeno u pojavi terorizma kao globalnog bezbednosnog problema. lako terorizam nije novi fenomen, globalne društvene promene koje su na sceni u velikoj meri utiču na karakter terorizma. One dovode do promena u trendovima, tendencijama i kretanjima terorizma što utiče na aktuelni i mogući terorizam. Pri tome se javljaju novi pojavni oblici terorizma i do izražaja dolaze, određene, specifične karakteristike terorizma.

Po određenju pojma terorizam, potrebno je poći od etimološkog značenja reči terorizam koja je nastala od latinske reči teror, što znači intenzivan strah ili francuske reči terreure, što znači sejanje straha. ${ }^{25}$

Terorizam, predstavlja izražen izazov globalnoj bezbednosti i javlja se kao globalni bezbednosni problem. Tome su doprineli značajni geopolitički događaji i globalne društvene pojave, kao rezultat tih događaja. Terorizam se može posmatrati istovremeno sa više aspekata. Najznačajniji od tih aspekata su oni koji terorizam osmatraju kao globalnu bezbednosnu pretnju, uzimajući u obzir da je terorizam jedan od najopasnijih oblika ugrožavanja bezbednosti država, regija i međunarodne zajednice u celini i kao takav predstavlja uverljivu pretnju bezbednosti (i opstanku) pojedinih država i globalnu pretnju bezbednosti međunarodnoj zajednici. ${ }^{26}$

Činjenica da terorizam predstavlja bezbednosnu pretnju savremenom svetu, moguće je naći u posthladnoratovskom uređenju sveta na principima globalizacije i uspostavljanja "novog svetskog poretka". Naime, proces globalizacije i uspostavljanja "novog svetskog poretka", čiji je lider SAD, ne doživljavaju sve države na isti način, niti su ovi procesi jednaki za sve države. Kao posledica navedenih procesa paralelno su se javile dve suprotne tendencije:

1. nestajanje opasnosti od rata između vodećih država sveta (trećeg svetskog rata, nuklearnog rata),

2. istovremeno mnoštvo unutrašnjih oružanih sukoba i manje međunarodnih ratova. ${ }^{27}$

Upravo ovakvi sukobi, etnički i nacionalno motivisani, jesu pogodno tlo za izrastanje, terorizma u najvećoj pretnji po bezbednost država, budući da takva područja, predstavljaju izvor nasilja, pogodnost za lociranje terorističkih kampova za obuku terorista, trgovinu oružjem, jačanje religioznog fundamentalizma, širenje nasilja, itd. Ovome treba do-

\footnotetext{
${ }^{25}$ Šikmn Mile: Terorizam - aktuelni mogući oblici, Banja Luka, 2006, str. 66-67.

${ }^{26}$ Milan Mijalkovski: Terorizam, Fakultet civilne odbrane, 2004, str. 6.

${ }^{27}$ Smilja Avramov: Trilateralna komisija, svetska vlada ili svetska tiranija, Ideja Veternik, 1998, str. 104.
} 
dati težnju terorista za postizanje dva globalna cilja: prvi, sagledavanje aktuelne vlasti u nekoj zemlji ili njenog redefinisanja i drugi, razbijanje teritorijalnog integriteta neke države. Postizanje ovih ciljeva najlakše je u državama sa nestabilnim društveno-političkim uređenjem, a ponekad ove države i same pribegavaju primeni terorizma (državni terorizam) kao najopasnijem obliku političkog nasilja. Terorizam je od kraja hladnog rata, u neprestanom porastu i zato analitičari upozoravaju na realnu opasnost da svet može olako kliznuti u epohu terorizma u kojoj bi terorizam bio najveća pretnja bezbednosti država, regiona i međunarodne zajednice.

Terorizam je višedimenzionalni društveni fenomen, te je u određivanju njenog pojma potreban multidisciplinaran pristup. Tako se terorizam može posmatrati sa aspekta politike, kriminalistike, kriminologije, krivičnog prava. Sa aspekta kriminalistike, terorizam je vrsta organizovanog kriminala, te je u sprečavanju i suzbijanju terorizma potrebno koristiti naučne ili na praktičnom iskustvu zasnovane metode i sredstava koja su najpogodnija da se terorističko delo otkrije i razjasni, otkriju teroristi i obezbede dokazi, kao i da se spreči izvršavanje planiranih terorističkih akata. Kriminološki pristup pojavi terorizma, ogleda se u izučavanju pojavnih oblika i uzroka terorizma (etiologija i fenomenologija terorizma), kao i mera za sprečavanje i otklanjanje terorizma kao oblika kriminaliteta. Krivično-pravne teorije posmatraju terorizam tako što pod terorizam podvode više krivičnih dela koja čine jedno krivično delo terorizma. Prema nekim autorima, potrebno je da postoje politički motivi, dok je prema drugima potrebno da su teroristički akti izvršeni organizovano, ali u svakom slučaju mora da nastupi opšta opasnost za ljude i imovine. ${ }^{29}$

Međutim, konsenzus o pojmu do sada nije postignut, odnosno različiti su pristupi u određivanju pojma terorizma.

Problem definisanja terorizma decenijama predstavlja izvor nesporazuma među državama, zbog čega ni danas nema zajedničkog stava o definiciji terorizma. O ovom problemu vodeći svetski stručnjaci imaju oprečne stavove. Valter Loker (Walter Lequeur) dokazuje da je nemoguće definisati terorizam, Aleks Šmit (Alex P. Schmidt), navodi da je uzaludno nastojanje da se odredi neka sveobuhvatna definicija terorizma, dok Brus Hofman (Bruce Hoffman) ukazuje na karakteristike terorizma koje ga bitno razlikuju od drugih oblika nasilja.

Hofman navodi da postoji jedna stvar sa kojom se svi slažu, a to je da je terorizam pežorativan termin. Po njemu, to je reč sa izrazito negativnom konotacijom koja se obično upotrebljava za neprijatelja ili suparnike ili za one sa kojima se čovek ne slaže i koje bi inače, želeo ignorisati.

Razvijanje zajedničkog shvatanja i definisanja terorizma obezbedila bi se potpuna saglasnost i univerzalan odgovor o pojavnom određenju i suštini terorizma. Dvostrukost standarda, a time i dvostrukost morala u međunarodnoj politici se ogleda i na planu definisanja pojma terorizma. Sve zemlje, a naročito velike sile, beskompromisno iskorenjuju onu vrstu terorizma koja im preti. Međutim, kada je u pitanju terorizam u „tuđem dvorištu", nemali broj zemalja se ponaša krajnje interesno, a time često i suprotno međunarodnom pravu, idući sve do granice otvorene podrške nekoj formi terorizma. Opredeljenje

\footnotetext{
${ }^{28}$ Vejnović Duško, Šikman Mile: Defendologija - društveni aspekt bezbednosti moderne države, Drugo izdanje, Banja Luka, 2007, str. 210.

${ }^{29}$ Vejnović Duško, Šikman Mile, Slobodan Radulj: Društveni aspekti terorizma, Banja Luka, 2006, str. 18.

${ }^{30}$ Brus Hofman: Unutrašnji terorizam, Narodna knjiga, Beograd, 2000, str. 26.
} 
za podršku nečijem terorizmu je uvek i taktičko opredeljenje protiv onoga kome je taj terorizam usmeren. Samim tim je i logično što države koje podržavaju nečiji terorizam, ne nazivaju taj terorizam terorizmom, već gerilom ili oslobodilačkim pokretom iako pojava ne ispunjava osnovne uslove da bi bila tako nazvana. ${ }^{31}$

Koliko je teško definisati terorizam govori i podatak da su Šmid (Alex P. Schmidt) i Jongman (Albert J. Jongman) u svom delu „Politički terorizam“, 32 analizirali 109 definicija terorizma, kako bi definisali neku opšte prihvatljivu, ali ni njihova 110 definicija nije postala opštepriznata.

U svom delu „Terorizam - opšti deo”, ${ }^{33}$ autor navodi da najveći broj definicija terorizma uključuje jedan od ova tri elementa: nasilje kao metod, građana i vladu kao mete, izazivanje straha i iznuđivanje političkih ili socijalnih promena kao nasilje. On dalje navodi da je terorizam izrazito politička pojava, da uvek nastaje sa političkim namerama i uvek egzistira u polju politike. Ukoliko ne postoji politička motivisanost, odnosno političi cilj, ne može se govoriti o terorizmu. Terorizam uvek predstavlja borbu protiv neke i nečije politike, odnosno protiv neke političke vlasti i pokušaj zasnivanja sopstvene. Takođe, i posledice terorizma su uvek i političkog karaktera. ${ }^{34}$

Terorizam, kao složena pojava, klasifikuje se prema različitim kriterijumima. Sve klasifikacije termina imaju prevashodno teorijski i metodološki karakter i međusobno se ne isključuju. Kada je reč o tipologiji, terorizam kao sistem klasifikovanja, potrebno je napomenuti da tipologija terorizma ima isto koliko i definicija terorizma. Različiti autori navode različite tipologije terorizma. Jedna od podela terorizma je na unutrašnji i međunarodni, zasnovano na lokaciji date terorističke akcije, državljanstvu izvršilaca i žrtava. ${ }^{35}$

Dragan Simeunović smatra da je najcelishodnija, najpreciznija i najsveobuhvatnija klasifikacija koja se vrši prema glavnim ciljevima terorizma, odnosno prema programskoj orijentaciji terorista, prema njihovim pretežnim metodama i sredstvima i prema tipu aktera-subjekata terorizma. Dalje, on prema programsko-ciljnoj orijentaciji terorizam deli na tri grupacije:

a) ideološki motivisan terorizam

- levičarski terorizam

- desničarski terorizam

b) etno-separatistički terorizam

v) verski fundiran terorizam

- terorizam sekti

- terorizam fundiran na interpretacijama velikih religija

\footnotetext{
${ }^{31}$ Dragan Simeunović: Teroroizam - opšti deo, Biblioteka Crimen, Beograd, 2009, str. 7.

${ }^{32}$ Alex P. Schmidt, Albert J. Jongman: Political Terrorisim: A New Guide to Aetros, Authors, Concepts, Data Bases, Theories and Literture, $\left(2^{\text {nd }}\right.$ ed) 1998.

${ }^{33}$ Dragan Simeunović: Terorizam-opšti deo, Bibloteka Krimen, Beograd, 2009, str. 33-35.

${ }^{34}$ Isto, str. 66.

${ }^{35}$ Termin, „međunarodni” terorizam nije najadekvatiji, s obzirom na to da do sada nije registrovan slučaj da je međunarodna zajednica bila nosilac čak nijednog terorističkog akta, a kamoli serije ovakvih akata nasilja. Međutim, danas je u svetu registrovana aktivnost preko stotinu državnih terorističkih kolektiviteta, ali nije registrovan nijedan međunarodni teroristički kolektivitet, iako je pouzdano utvrđeno da, na primer islamsku teroristički mrežu Al Kaida čine državljani više desetina zemalja. Izvor: Milan Mijalkovski, FCO, Beograd, 2005, str. 31.
} 
Teroristi će uvek koristiti ono sredstvo koje najviše može da zastraši, a koje oni mogu da poseduju i znaju da upotrebe. Često se gubi iz vida složenost terorizma kao pojave pa se sva pažnja obraća samo na njegovu nasilnu dimenziju. Terorizam pak, predstavlja složenu delatnost sastavljenu od niza specifičnih aktivnosti koje same po sebi nisu nasilne, a nužne su da bi teroristička organizacija mogla da funkcioniše. Na primer, finansiranje, propaganda, mobilizacija članstva i simpatizera, kao i brojne druge aktivnosti predstavljaju načine ili metode održavanja jedne terorističke organizacije funkcionalnom. Ona ne može da postoji i da funkcioniše bez finansijskih i drugih sredstava, bez članstva i bez određenih oblika podrške. Ipak, ukupnost metoda u nekoj sferi terorizma koji ga ponajviše profilira, određuje i tip terorizma.

Ipak ova podela je najcelishodnija kada je izvršena prema više povezanih kriterijuma: njihovoj brojnosti, stepenu organizacione povezanosti i institucionalnoj dimenziji.

Podela zasnovana na ovima kriterijumima izgleda ovako:

a) individualni terorizam

b) terorizam organizacija i ilegalnih grupa

v) institucionalni terorizam. ${ }^{36}$

Verski terorizam (ili kako ga mnogi i nazivaju religijski) sprovode verski zaslepljene terorističke grupe na osnovu verske indoktrinacije. Cilj verskih fanatika jeste da iz temelja promene vladajuće društveno-političke odnose i uspostave nivo državno-političko uređenja na religijskim osnovama. Ispoljava se i kao terorizam fanatičnih grupa koje izvode terorističke akcije radi utemeljenja religijskih vrednosti u društvu. ${ }^{37}$

Religija je tokom istorije odigrala veliku ulogu u obuzdavanju nasilja, suzbijanja agresije, kao i promovisanju pomirenja i razumevanja među suprotstavljenim grupama. Međutim, kao što nas istorija uči, religija može biti posredno ili neposredno uzrok ratova, terorizma i drugih oblika nasilja. Ne može se tačno definisati krajnji cilj religije i njen odnos prema društvenom nasilju, ali ono što znamo je da početkom 21. veka dolazi do povezivanja religije i terorizma. Religija i terorizam dolaze u vezi onda kada se religiozne ideje podrede političkim, etničkim ili ideološkim ciljevima. ${ }^{38}$

Verski terorizam se ispoljava kroz proklamovanje tri vrste ciljeva u smislu apokaliptičkog uništenja sveta, uspostavljanja verskih vlasti u državi, te stvaranje verski čistog stanja. Tokom istraživanja Džonatan Vajt (Vajt R. Jonatan) je ustanovio da su apokaliptička doktrina i terorizam postali opasni saveznici. Kada se primeni na terorizam, apokaliptična doktrina poziva teroriste da se bore kao sveti ratnici u svom fanatičkom zanosu, gde božanstvo završava proces stvaranja. Oni veruju da vladavina Boga samo što nije počela i da im je ovo poslednja prilika da očiste proces stvaranja pre nego što Bog zavlada. ${ }^{39}$

Koreni religijskog terorizma po Radoslavu Gaćinoviću ${ }^{40}$, potiču iz perioda pre nove ere i vezuje in za Jevrejsku sektu „Ziloti”. Ziloti su bili jevrejska grupa koja se borila protiv rimske uprave u Palestini u periodu između 66-73 godine nove ere. Ziloti su ve-

\footnotetext{
${ }^{36}$ Dragan Simeunović: Terorizam - opšti deo, Biblioteka Krimen, Beograd, 2009, str. 82-85.

${ }^{37}$ Miroslav M. Talijan: Bezbednosni menadžment u suprotstavljanju terorizmu i borbu protivterorizma, Medija centar Odbrana, Beograd, 2012, str. 39.

${ }^{38}$ Brus Hofman: Unutrašnji terorizam, Narodna knjiga, Beograd, 2000, str. 65.

${ }^{39}$ Džontan Vjat: Terorizam, Aleksanrija pres, Beograd, 2004, str. 4.

${ }^{40}$ Radoslav Gaćinović: Terorizam, Drasler, Beograd, 2005, str. 99.
} 
rovali da su pozvani od Boga da vode rat protiv sila mraka, tj Rimske carevine, te da je takav rat neizbežan ako žele da se pokoravaju Božjoj naredbi da ne poštuju nikakvog vladara nad Izraelom osim Boga. Oni su koristili metode koje se potpuno uklapaju u današnje shvatanje terorizma: vršili su nasilje protiv Rimljana ali i Grka i Jevreja koji su sarađivali sa rimskom vlašću (atentati omiljenim oružjem Zilota - malim bodežom zvanim sica, ${ }^{41}$ napadi su bili neočekivani na javnim mestima u vreme praznika). Objekti napada su imali simboličku vrednost (rimski službenici, istaknuti Jevreji koji su sarađivali sa Rimljanima) a ciljevi Zilota bili su politički (da ukinu rimsku vlast i uspostave, jevrejsku teokratsku državu u Palestini). ${ }^{42}$

Kasnije, verski terorizam se eksponirao kroz stravično nasilje hindu sekte „Tagi” u periodu između 7. i 9. veka. Tagi su bili članovi tajne organizacije obožavatelja božice Kali, hinduskog simbola terora i razaranja. U članstvo organizacije se ulazilo putem razrađenog religijskog ceremonijala. Tagi su se okupljali u mesecu oktobru, delili u grupe a zatim izlazili na indijske drumove da presreću bogate trgovce. Ubijali bi ih davljenjem, pokopavali a zatim uzimali njihovu imovinu. Opljačkanu imovinu bi međusobno delili ostavljajući uvek jedan deo za hramove podignute u čas boginje Kali. Tagi nisu napadali one za koje su verovali da su potomci Božice Kali - žene, lutalice, slepe i sakate. Nesmetano su delovali vekovima na području Indije, a u 19. veku, kada je grupa usmerila napade protiv predstavnika britanske vlasti, usledila je energična državna akcija. Tokom kampanje koja je vodio Sir W. H. Sleeman (1788-1856) oko 3.000 članova ove organizacije pogubljeno ili poslato u zatvore a sama organizacija je razbijena. ${ }^{43}$

Verska sekta „Asasini”, je još jedna verska sekta koja je označena kao preteča verskog terorizma. Asasin (ubica, atentator koji ubija drugog na podmukao i nasilan način), a arapski (ar. hašišin „oni koji jedu hašiš”) je termin korišćen da označi pripadnike šitskih ismailija , koji su bili aktivni u Oranu i Siriji između 1090. i 1272. godine. Teorijsko učenje grupe i temelje organizacije grupe dao je Hasan ibn al Sabah (1050-1124), zasnovavši ga na etničkoj grupi Niziri. On je propagirano povlačenje (hidžra) u izolovana mesta i organizovanje života prema islailijskom učenju. Mete su bili seldžučki službenici, krstaški vitezovi, sunitski učenjaci koji bi se izjasnili protiv Nizarija i slično. Žrtve su redovno ubijali na javnom mestu i uvek bodežom, nikada otrovom niti strelama. Nasilje je za asasine bio čin svete tajne, Božija dužnost koju propisuje sveta knjiga i prenose crkvene vlasti. S tim u vezi, nasilje asisina imalo je za cilj, ne samo da se pobede hrišćanski neprijatelji, već i da se ubrza dolazak novog milenijuma. Važan dodatni motiv za jednog asisina bilo je obećanje da ako pogine u toku izvođenja napada odmah odlazi na veličanstveno nebo. ${ }^{44}$

Osim ovih slučajeva verskog terorizma pojedinih grupa koje su se pojavile u okviru Jevrejstva, Islama i Hinduizma, istorija beleži i pojavu religijski inspirisanog institucionalizovanog terora. Primer za to je Inkvizicija Katoličke crkve u doba srednjeg veka. ${ }^{45}$ Inkvi-

\footnotetext{
${ }^{41}$ Hatidža Beriša: Političko nasilje na Kosovu i Metohiji, doktorska disertacija, FNP, Beograd, 2012, str 175-185.

${ }^{42}$ Dragan Simeunović: Terorizam - opšti deo, Biblioteka Crimen, Beograd, 2009, str. 97-100, smatra da je reč o širokom narodnom ustanku u okviru koga su pojedine manje grupe ustanka ponekad i vršile izuzetno brutalne prepade izazivajući užas kod rimskih osvajača, a ne o terorizmu.

${ }^{43}$ Isto, str. 99-120.

${ }^{44}$ Brus Hofman: Unutrašnji terorizam, Narodna knjiga, Beograd, 2000, str. 80.

${ }^{45}$ Dictionary of Middle Ages ed Joseph R.Strayer (New York: Shareles Scribner's Sons, 1985) p. 483-489.
} 
zicija je bila pravna institucija uspostavljena od strane Pape sa zadatkom da pronalazi, optužuje i osuđuje lica osumnjičena za herezu (odstupanje od službenog crkvenog učenja). Protiv osumnjičenih osoba bila je dozvoljena upotreba torture.

Ono što je zajedničko za Zilote, Asasine, Tagove i Inkviziciju jeste da je nasilje vršeno u ime religije i opravdano pozivanjem na religijsko učenje. Ovakva situacija dominirala je predmodernim dobom iz jednostavnog razloga što je $u$ to vreme dominantni pogled na svet bio religijski te su sve aktivnosti opravdane pozivanjem na religiju. Naglašenost religije kao glavnog pokretača terorističkih aktivnosti, posebno je došla do izražaja tokom devedesetih godina prošlog veka. ${ }^{46}$ Činjenica je da su najozbiljniji teroristički akti tog perioda, bilo u smislu političkih implikacija i posledica ili broja žrtava, imali zajedničku versku dimenziju i/ili pobude. ${ }^{47}$ Početkom 21 . veka terorističke grupe prihvataju daleko amorfnije religijske ciljeve, organizaciono su manje kohezione, s labavijom strukturom i heterogenim članstvom, a pored tog etničkog sukoba često poprimaju oblike verskih sukoba, jer se uz pitanje etničke pripadnosti i teritorijalnih problema, kao centralna i najvidljivija razlika između grupe pojavljuje i religijska. Ova činjenica je aktuelna i danas, jer smo svedoci da su verski fundamentalistički pokreti poslednjih godina značajno ojačali. Naime, religija se često smatra višim zakonom od državnih zakona i međunarodnih sporazuma. Posledica ovako suprotstavljenih vrednosti i prakse su nasilni sukobi, koji se vode u ime pojedinih religija. Različito motivisani pripadnici pojedinih religija posebno su obeležili svetsku kartu naslinih sukoba posle hladnog rata, od kojih se Islam posebno ističe.

Islamski fundamentalizam, svoju snagu je crpeo iz džihada. Oni džihad poimaju, isključivo u formi svetog rata protiv nevernika (nevernici su svi oni koji nisu muslimani) ili veroodstupnika (muslimani koji su odstupili od one vrste islama, koju propagiraju islamistički fanatici, kao način života). Džihad je postao glavno obeležje i oličje islamističkog terorizma i jedno od najjačih oruđa u rukama islamističkih terorista i njihovih mentora, u njihovoj borbi za ostvarivanje krajnjeg cilja.

\section{Džihad kao izvorište globalnog terorizma}

Krajem 20. veka i početkom 21. veka na svetsku scenu naglo je izbio islamski fundamentalistički odnos prema terorizmu kao oruđu za postizanje sopstvenih ciljeva. Razvoj događaja koji su se odvijali poslednjih decenija a posebno događaji od 11. septembra 2001. godine, imali su za posledicu drastično povećanje broja organizacija i pojedinaca sa muslimanskim identitetom ili islamskom samoidentifikacijom na listama grupa umešanih u terorizam. Na primer, sveobuhvatna lista terorista i grupa identifikovanih Izvršnom uredbom broj 13224 (Comprehensive List of Terrorists and Groups Identified Under Executive Order 13224), predsednika SAD od 23. septembra 2001. godine, obuhvata 189 grupa, entiteta i pojedinaca. Od tog broja 149 uključenih ima muslimanski identitet, vidljiv po ličnom ili nazi-

\footnotetext{
${ }^{46}$ Broj religijskih terorističkih grupa povećao se 1990. godine u odnosu na 1970. godine povećao se 2 na 11. godine 1974. takvih grupa je bilo 16 (od ukupno 49 identifikovanih grupa). Godine 1995. takvih grupa popeo se na 26 (od ukupno 56 identifikovanih grupa). Sledeće godine, poslednje za koje je autor ima kompletne statističke podatke, broj takvih grupa je pao na 13 (od ukupno 46 identifikovanih). Detaljnije videti: Brus Hofman: Unutrašnji terorizam, Narodna knjiga, Beograd, 2000, str. 81.

${ }^{47}$ Brus Hofman: Unutrašnji terorizam, Narodna knjiga, Beograd, 2000, str. 11.
} 
vu grupa ili entiteta. Na listi stranih terorističkih organizacija (STO) koje su imenovane od strane državnog sekretara SAD u skladu sa članom 219. Zakona o imigracijama i državljanstvu, sa izmenama i dopunama nalaze se 56 terorističkih organizacija od kojih je 30 sa islamskom samoidentifikacijom. ${ }^{48}$ Džihad je pojam koji se svaki dan sreće u sredstvima javnog informisanja i svetskoj politici. To je sasvim logično posle svega što se desilo 11. septembra 2001. godine. Zato što je tada izvedena akcija protiv SAD, koja je rezultirala rušenjem dve zgrade Svetskog trgovinskog centra i oštećenjem Pentagona, povezana sa tim pojmom. Istraga izvršena od strane FBI je konačno dokazala da su svi učesnici u akciji muslimani i da su tu akciju i izvršili pravdajući je verskim motivima. Tako se pokazalo da je džihad postigao najspektakularnije rezultate u ratu sa SAD. A uzrok svemu tome jeste džihad odnosno organizacija Al Kaida koja se na njega poziva. ${ }^{49}$

Džihad je permanentno stanje neprijateljstva prema nemuslimanima, gde se najčešće podrazumeva verski rat u službi širenja islama. Međutim, svaki rat jeste džihad, a svaki džihad nije rat. Džihad je postao sinonim za sveti rat, iako on u islamu ima složenije značenje. Grubi prevod džihada bi bio stremljenje ili naprezanje, koji podrazumevaju muslimani nastojeći da slede put Boga. Taj put Boga, predstavlja individualno nenasilno stremljenje da se živi ispravnim muslimanskim životom u skladu sa Božijom voljom. Takav život predstavlja pet stubova islama odnosno osnovnih religijskih dužnosti muslimana (islamskih vernika). Prvi stub jeste izgovaranje simbola vere islama a koji glasi: „nema drugog Boga osim Alaha, a Muhamed je Alahov poslanik“, Drugi stub je zagovaranje formalnih molitvi pet puta dnevno pre kojih se obavlja obredno pranje, pri čemu je tokom molitve vernik uvek okrenut prema svetom gradu Meki, bez obzira gde se na svetu nalazio. Treći stub predstavlja praznovanje ramazana, meseca strogog posta, tokom kojeg se hrana i piće ne uzimaju preko dana, nego tek kada sunce zađe. Četvrti stub jeste davanje milostinje (novac siromasima). Ovde je važno napomenuti da se ovaj oblik vrlo često koristi i kao oblik prinudnog iznuđivanja sredstava za finansiranja terorističkih akcija. Poslednji peti stub odlazak (bar jednom u životu) na hodočašće u Meki. ${ }^{50}$

Po mišljenju Miroljuba Jevtića, džihad je sistem svih akcija i postupaka na individualnom planu koji muslimani sprovode u cilju jačanja islamske religije i širenja zajednice vernika. Krajnji cilj džihada je kalifat. Kalifat, zapravo, predstavlja stvaranje jedinstvene muslimanske države na nivou planete zemlje, a na osnovu planetarnog širenja Muhamedovog učenja. Kalifat se može ostvariti samo džihadom. ${ }^{51}$

U početku antikolonijalna i nacionalno-oslobodilačka borba je kvalifikovana kao džihad, koncept koji u islamskom kategorijalnom aparatu predstavlja ekvivalent „pravednog rata“ (bellum iustum) zapadnih naroda. $U$ to doba situacija je bila jasna, muslimanske zemlje i narodi bili su potčinjeni od strane kolonijalnih sila, njihova borba za oslobođenje bila je legitimna. Zbog značaja islamskog nasleđa neki antikolonijalni pokreti koristili su Islam kao sredstvo legitimizacije oružane borbe i političke mobilizacije stanovništva. ${ }^{52}$ Ovakvo stanje stvari nastavilo je da postoji i u prvoj polovini 20. veka u vreme zenita antikolonijalne i oslo-

\footnotetext{
${ }^{48} \mathrm{http} / / /$ www.stategov/j/ct/rls/other/des/123085.htm)

${ }^{49}$ Hatidza Beriša i dr autori „The influnce of islamic onthe Global security“, Journal of Liberty and International Affairs, Specijal Isuse, Vol. 1 Supp. 1/2016, str. 49-59 .

${ }^{50}$ Mark Sejdžmen: Terorističke mreže, Altera, Beograd, 2006, str. 9-11.

${ }^{51}$ Miroljub Jevtić: Savremeni džihad kao rat, 3 izdanje, Nikola Pašić, Beograd, 2001, str. 20.

${ }^{52}$ Hadia Dajani: Shakeel and Ronald A. Meissir (eds), The Jihad and Its Times (Ann Arbor, Ml: Univrsity of Michigen Press, Rudolph Peters, Jihad in Classical and Modern Islam (Princeton: Markus, Wiene, 1996).
} 
bodilačke borbe u većem delu muslimanskog sveta. Situacija se radikalno menja 1970-tih. Ponižavajući poraz arapskih zemalja u ratu sa Izraelom 1967. godine i paljevina džamija Al-Aksa-trećeg islamskog svetog mesta, dovode do razočarenja muslimanskih masa u vladajuće ideologije i vođstva, posebno u arapskom svetu. Javljaju se brojne militantne grupe koje proglašavaju vladajuće muslimanske režime nelegitimnim i opravdavaju njihovo uklanjanje s vlasti nasilnim putem prikazujući to kao preduslov efikasnog muslimanskog suprotstavljanja Izraelu i drugim neprijateljima muslimanskog sveta. Ove grupe proglašavaju džihad protiv muslimanskih vlada i počinju vršiti napade na vladine predstavnike, institucije, stanice i slično, vršeći na taj način dela koja po svojim obeležjima potpadaju pod kvalifikaciju terorizma. ${ }^{53}$ Od poznatijih terorističkih organizacija koje su pribegle džihadu su na primer: Egipatska muslimanska braća, Hizb al-tahir al-Islam, (Partija islamskog oslobođenja), ${ }^{54}$ poznata po napadu na Vojnotehničku akademiju u Heliopolisu 1974. godine u Egiptu, Tanzim al-džihad (Organizacija džihada), koja je izvršila atentat na predsednika Egipta Muhameta Envera El Sadata 06. oktobra 1981. godine, kao i organizacija Al-Džama a alislamilia (Islamska grupa), poznata po najvećem broju akata političkog nasilja nakon 1991. godine, uključujući napad na grupu stranih turista u Luhoru 17. novembra 1997. godine, kada je ubijeno 66 osoba. ${ }^{55}$ Pored Egipta i u drugim islamskim zemljama postale su aktuelne terorističke organizacije koje se pozivaju na džihad kao što su: Hamas, Hezbolah, Islamska država i druge koje se nalaze na navedenom spisku SAD.

Sve do početka rata u Avganistanu koji je SSSR vodio od 1979. godine do 1989. godine protiv lokalnih pobunjeničkih naoružanih formacija, islamske terorističke organizacije i pojedine islamske zemlje koje su finansijski i organizaciono podržavale taj oblik terora delovale su uglavnom samostalno u svojim akcijama i među njima nije bilo neke povezanosti, niti sinhronizacije delovanja i akcija. Bar je to tako izgledalo na prvi pogled, jer se ni po čemu nije moglo zaključiti da postoji neko koordinaciono telo ili organizacija koja sinhronizuje aktivnost raznih terorističkih grupa i organizacija u svetu prema jednom usaglašenom zajedničkom cilju. Iz tog rata, međutim, islamski terorizam izašao je finansijski, kadrovski i organizaciono jači. Na takav razvoj događaja uticale su i SAD, koje su se u rat u Avganistanu umešale metodom prikrivenih akcija. Zbog svog interesa u tom delu sveta SAD su preko svojih tajnih službi naoružavale mudžahedine, organizovale i izvodile obuku sa njima, delile im znanje, tehniku i novac. Kadrove, borbe i ostatak finansijskih sredstva obezbeđivali su fundamentalistički krugovi, posebno neki od muslimanskih zemalja takozvane Grupe D-8 (najrazvijenije muslimanske zemlje). ${ }^{56}$ Tako je rat u Avganistanu učinio prekretnicu u razvoju islamskog terorizma. Posle ideje o sveislamskom bratstvu koja je je promovisana u tom ratu, javila se ideja o organizovanju islamske terorističke mreže koja bi povezivala sve islamske terorističke organizacije u jednu radi džihada (svetog rata) protiv svih protivnika. ${ }^{57}$

\footnotetext{
${ }^{53}$ Mark Sejdžmen: Terorističke mreže, Altera, Beograd, 2006, str. 29-56.

${ }^{54}$ Poznata po napadima na Vojno-tehničku akademiju u Heliopolisu 1974. Godine u Egiptu.

${ }^{55}$ Mark Sejdžmen: Terorističke mreže, Altera, Beograd, 2006, str. 29-36.

${ }^{56}$ Grupa D-8, sastavljena od osam islamskih zemalja u razvoju sa populacijom od oko 900 milion osoba, osnovana je 1997. godine, u cilju jačanja ekonomske saradnje, među članicama, aktivnog prisustva članica u svetskoj ekonomiji, stvaranje novih trgovinskih prilika, te poboljšanje života stanovništva. Grupu čine Iran, Indonezija, Bangladeš, Pakistan, Turska, Malezija, Egipat i Nigerija.

${ }^{57}$ Milan Petković: Terorizam - rat u kontinuitetu, Vojno delo, broj 4/2009, str. 259-260.
} 
$\mathrm{Na}$ osnovu takvih iskustava i ideja 1998. godine stvorena je organizacija Al Kaida (poznato još kao Islamska Armija za oslobođenje Svetih mesta, svetski islamski front za džihad protiv Jevreja i osvajača) globalna multinacionalna mreža koja povezuje razne islamske fundamentalističke organizacije iz više zemalja. Osnovali su je 1988. godine Osama Bin Laden (Usama Bin Laden) i Abudulah-Azem (Abdullah Azzem) u Kandaharu (Avganistanu), u početku radi okupljanja Arapa koji žele boriti protiv Rusa u Avganistanu, a kasnije radi okupljanja džihada širom sveta. Zasniva se na ideji sveislamskog bratstva i njen krajnji cilj je stvaranje jedinstvene islamske države (Uma), koja bi bila urađena prema islamskim propisima (vladanje po Kuranu i šerijatskim zakonima), a na čijem je čelu suveren i jedan gospodar - Bog (Alah). Ona poziva na sveti rat, proklamuje mučeništvo i odgovorna je za mnoge terorističke napade.

$\mathrm{U}$ istovremenim samoubilačkim terorističkim napadima na američke ambasade u Keniji i Tanzaniji avgusta 1998. godine, ubijeno je preko 300 osoba, a ranjeno je oko 500 ljudi. Izvršen je samoubilački napad na američki razarač „USS COLE“ u Jemenu u oktobru 2000. godine. Mnogi državnici SAD uključujući predsednika Džordža Buša, optužili su AI Kaidu za samoubilačke terorističke napade na SAD 11. septembra 2001. godine. Takođe, Al Kaida je preuzela odgovornost za četiri vezana samoubilačka napada u Rijadu maja 2003. godine. ${ }^{58}$

Za pripadnike Al Kaide, isto kao i za ostale učesnike u svetskom islamskom pokretu, koji svoju borbu karakterišu kao džihad, nema nikakve sumnje šta se iza tog pojma krije. Za Ajmana Al Zavaharija, koje SAD stavljaju na listi od 21 teroriste koje se najviše traženi od FBI i koji je predstavljen kao jedan od najvernijih saradnika Osame Bin Ladena, džihad je jasno definisan. Za njega se kaže da da je jedan od osnivača egipatskog „Islamskog džihada", čiji je član Haled al Islambuli ubio egipatskog predsednika Sadata. U ideologiji pisca brošure „Zanemarena obaveza“, Abdul Sadama Faradža, jednog od vođe grupe „Džihada“ i saborac Ajmana al Zavahirija o džihadu se kaže sledeće: „Jedina prihvatljiva forma džihada jeste oružana borba. Islam je uostalom borbena religija i uvek se nametao silom". Zatim se dodaje: „Muslimani danas žive u vreme ratnih zakona. Zakoni koji regulišu odnose sa okolinom su ratni zakoni i muslimani imaju pravo da ubiju onoga ko preti zajednici vernika. Prvi da oceni ko ugrožava zajednicu vernika ili grupa „Džihad“. ${ }^{59}$

Iz navedenog se jasno vidi da je osnovu ideologije grupe Džihad još mnogo pre, čak pre dve decenije, bilo jasno kako oni, koji misle isto kao Al Kaida i koji su se sa njom spojili, definišu džihad. Bilo je, dakle jasno da će sledbenici takve ideologije nastojati da koriste oružanu borbu kao jasnu prihvatljivu formu džihada, ratovati protiv svih koje smatraju neprijateljima. A to su i SAD i NATO, ali pre svega Izreal i vlade islamskih zemalja koje su ocenjene kao veroodstupničke.

Novi oblik terorizma nazvan „globalni džihad“, popularno se tumači kao „kontraefekat“ koji je napravila američka vlada, time što je obučavala i podržavala „avganistanske Arape“. Direktna posledica avganistanskog rata su grupe sa ogromnim borbenim iskustvom i tvrdokornom militantnom ideologijom. Ovi borci su postali okosnica i najveća snaga svih kasnijih islamskih terorističkih grupa. Nakon napada, 11. septembra 2001. godine, Al Kaida je u SAD postala sinonim za terorizam, ali u stvarnosti organizacija AI Kaida igra vodeću ulogu u većem političkom i vojnom pokretu zvanom „globalni džihad“. Globalni dži-

\footnotetext{
${ }^{58}$ Predrag Micić: Samoubilački terorizam, Altera, 2006, str. 93-94.

${ }^{59}$ Miroljub Jevtić: Savremeni džihad kao rat, 3. izdanje, Nikola Pašić, Beograd, 2001, str. 67.
} 
had je ekstremistička frakcija unutar islamizma, široko rasprostranjen religijski pokret koji teži pooštravanju usađivanja Islama u politiku, ekonomiju i društvo. Globalni džihadizam deli pogled na svet u kojima muslimanski svet trpi produžen agresivni napad Zapada, vođen od strane SAD. Politika SAD u promovisanju demokratije širom muslimanskog sveta, viđena je kao drugačiji oblik napada na Islam. Globalni džihad se protivi u bilo kom obliku sekularizmu: demokratija, nacionalizam i bilo koji drugi neislamski sistem filozofije. ${ }^{60}$

Globalne promene u svetu uticale su povoljno na razvoj terorizma. Sa jedne strane naučno-tehnološki razvoj koji se smatra zamajcem globalizacije, doveo je do toga da se tehnološki napredak koristi i za osavremenjavanje terorističkih akcija. Na drugoj strani, imamo pojavu terorizma, kao posledicu suprotstavljanja procesima globalizacije. Snažni nacionalizmi koji su nastali kao reakcija na globalizaciju uslovljeni su nastojanjima politike vladajućih svetskih država da se u ime utemeljenja „svetskog društva“ ponište nacionalni identiteti, odnosno uslovljeni su i sve snažnijim osećanjem egzistencijalne ugroženosti zemlja periferije sveta. Prinudno nametanje novog modela sve se snažnije doživljava kao nešto što nameće Zapad. Politički islam, u raznim oblicima, postaje sve privlačniji za milione muslimana širom Bliskog Istoka, severne Afrike, a neke radikalne varijante predstavljaju snažne razloge za socijalne i političke podele. Intervencionalizam je, međutim, relativizovao snagu islamskog džihada koji se kao bumerang vratio nosiocima intervencionalizma. Koristeći opštenarodno nezadovoljstvo islamskih naroda amerikanizaciji kulturnih vrednosti, pojedine organizacije su pod džihadom stvorile moćne terorističke organizacije koje danas predstavljaju ozbiljnu bezbednosnu pretnju svetskih razmera.

\section{Zaključak}

Danas, je evidentno da svet sa globalizacijom postaje tehnološko-ekonomski sve povezaniji ali i sve konfliktniji. Ispostavilo se da takav globalistički model međunarodnih odnosa predstavlja osnov porasta globalne nestabilnosti, nasilja i destrukcije, čak i apokaliptičkih pretnji ljudskoj civilizaciji .

Globalizacija bez sumnje predstavlja jedno od najkompleksnijih polja naučnog interesovanja. Poseban problem je činjenica da je savremena stvarnost, čiji je najznačajnije obeležje globalizacija, prožeta brojnim protivurečnostima.

Tehnološka revolucija i inovacije koje je ona donela revolucionarno su uticale na društvena kretanja savremenog sveta, menjajući njegovu društvenu strukturu i vrednosni sistem. Principi racionalnosti i efikasnosti postali su osnova preuređenja sveta, a sve veća međuzavisnost pojedinca, grupa i političkih zajednica doprinela je jačanju svesti o mogućnostima uspostavljanja globalnog svetskog društva. Istovremeno, tehnološka revolucija, posebno njeni dometi u informatičkoj tehnologiji, omogućavaju jačanje svesti o dramatičnom porastu nejednakosti u raspodeli svetskog bogatstva i ugrožavanja etničkih i civilizacijskih identiteta širom sveta.

Proces univerzalizacije osnovnih vrednosti, praćen isključivošću i diskreditovanjem i diskvalifikovanjem kulturnog nasleđa i tradicija, podstakao je ekspanziju brojnih tradicionalističkih pokreta. Nejednakost siromaštva i politička obespravljenost moćan su činilac takvih

\footnotetext{
${ }^{60}$ Sarah E Zabel: The Military Strategy of Global Jihad, Strategic Studies Institute, Uni fed States Army War College, 2007. Preduzeto: htto://strategistudiesinstitute.army.mail/pubs/display.cfm?pubID=809
} 
tendencija i generisanja etničkih animoziteta i sukoba. Sukobi u kulturi i sve snažniji otpor poništavanja vlastite kulture, idu u prilog predviđanja da će u milenijumu koju je otpočeo sukob ideologija, karakterističan za bipolarnu podelu sveta, zameniti sukob civilizacija.

Terorizam u uslovima globalizovanog sveta poprima globalne razmere i prerasta $u$ alarmantnu vrstu nasilja i sveopšte nesigurnosti i ugroženosti. Kao taktika slabih protiv jakih, globalni terorizam je posledica političkih i ekonomskih frustracija ogromnog dela savremenog sveta.

U oblasti religijski inspirisanog ekstremizma i terorizma uočiva se naglašena tendencija pripisivanja islamu ekskluzivnog statusa jedne religije koja propagira i stimuliše ovaj oblik političkog nasilja. Istina je, svakako, nešto drugačija. Ukoliko sa istorijskog aspekta posmatramo nastajanje i delovanje najvećih religija čovečanstva, nailazimo na nebrojene primere protezanja za nasiljem u cilju njihovog širenja. Primeri „Svete inkvizicije“ u hrišćanstvu i starozavetnih krvavih obračuna u judaizmu svedoče o tome. I danas egzistiraju ekstremističke organizacije koje su inspiraciju našle u savremenim religijama današnjeg sveta (primeri u budizmu, judaizmu, kod hrišćana-desničara i sl). Ipak, nemoguće je negirati da su islamske zemlje uzele učešće u 2/3 modernih ratova, kao i da se najveći broj ekstremističkih zalaganja i terorističkog delovanja u najnasilnijim formama odvija u organizaciji pripadnika „muslimanskog sveta“.

Međutim, ozbiljna greška bila bi traženje utemeljenja savremenog islamističkog ekstremizma isključivo u sferi religije. Ova vrsta nasilja prvenstveno je produkt interesa određenih političkih snaga koje su na vlasti u pojedinim muslimanskim zemljama ili koje tome tek teže. Religija im, u ovom slučaju, samo služi kao moćan pokretač iracionalnog ekstremno-fanatizovanog ponašanja izvesnog broja vernika. U takvom miljeu od strane fundamentalista koji se često pozivali na džihad, terorizam je prihvaćen kao najefikasnije sredstvo delovanja. Terorizam je najpre korišćen kao sredstvo borbe protiv evropskih kolonijalnih sila u Africi, zatim, druga njegova uloga bila je da posluži kao sredstvo za svrgavanje sekularnih režima i uspostavljanja fundamentalističkih društva sa šerijatskim zakonima. Treća njegova uloga shvaćena je kao sredstvo osvete prema zapadnoj civilizaciji i Zapadnim državama, jer su oni shvaćeni kao glavni uzroci svih problema u islamskom društvu.

Islamski fundamentalisti su džihad izjednačavali sa svetim ratom, i kao takvog su ga koristili kao ideološku osnovu za masovnu mobilizaciju i učestvovanje muslimana u ratovima koji su vođeni protiv „nevernika“. Ovi ratovi su vođeni sa ciljem osvajanja novih teritorija i širenja islama prinudom i oružanom silom. Pojam džihada je ponovo aktuelizovan početkom osamdesetih godina prošlog veka, tokom rata u Avganistanu, kao i početkom devedesetih godina prošlog veka u delovanju brojih islamskih terorističkih organizacija. Ono što danas posebno zabrinjava je pojava mučeništva. Status mučenika se stiče žrtvovanjem sopstvenog života u toku vođenja džihada - Svetog rata. Ideja mučeništva je snažno uticala na pojavu relativno novog oblika islamskog terorizma - samoubilačkih akcija.

\section{Literatura}

[1] Avramova, S., Trilateralna komisija, svetska vlada ili svetska tiranija, Ideja Veternik, 1998.

[2] Bjelić I. D., Globalizacija i otpori, Nova srpska politička misao, Nova edicija, VII, br. 3-4.

[3] Beriša H., Političko nasilje na Kosovu i Metohiji od 1945 do 2003. godine, doktorska disertacija, FNP, Beograd, 2012.

[4] Beriša, H, i drugi autori., „The influnce of islamic onthe Global security“, Journal of Liberty and International Affairs, Specijal Isuse, Vol. 1 Supp. 1/2016), Bitol, 2016. 
[5] Beriša, H, i autori: „Međusobni uticaj procesa globalizacije i terorizam”, Međunarodni naučni skup: Određenje, organizacija i djelatnost subjekata nacionalnih sistema bezbednosti, FBZ, Univerzitet sinergija, Banja Luka, 26.10.2014.

[6] Vjat, Dž., Terorizam, Aleksanrija pres, Beograd, 2004.

[7] Volerstin, I., Opadanje američke moći, Podgorica, 2004.

[8] Vidojević, Z., Kuda vodi globalizacija, Filip Višnjić, Beograd, 2005.

[9] Vejnović D, Šikman M.: Defendologija - društveni aspekt bezbednosti moderne države, Drugo izdanje, Banja Luka, 2007.

[10] Vejnović D, Šikman M, Slobodan R., Društveni aspekti terorizma, Banja Luka, 2006.

[11] Gaćinović, R., Terorizam, Drasler, Beograd, 2005.

[12] Gidenes E., Globalizacija shvaćena ozbiljno, Republika, Beograd, 2000.

[13] Gidens E., Posledice modernosti, Filip Višnjić, Beograd, 1998.

[14] Jevtić, M., Savremeni džihad kao rat, 3. izdanje, Nikola Pašić, Beograd, 2001.

[15] Naj, Dž., Paradoks, američka moć, BMG, Beograd, 2004.

[16] Marković Ž, D., Globalizacija obrazovanja, Zbornik radova sa naučnog skupa osnovna polazišta obrazovanja, Srpska akademija obrazovanja, Beograd, 2006.

[17] Milašinović, R, Milašinović, S., Uvod u teoriji konflikata, FB, Beograd, 2004.

[18] Micić, P., Samoubilački terorizam, Altera, 2006.

[19] Mijalkovski, M., Terorizam, Fakultet civilne odbrane, 2004.

[20] Pečujlić, M., Globalizacija dva lika sveta, Gutenbergova galaksija, Beograd, 2002.

[21] Pečujićc. M,: Planetarni kentaur, Nova srpska politička misao, Nova edicija, vol. VII, PO 3-4, Beograd

[22] Petković, M., Terorizam-rat u kontinuitetu, Vojno delo broj 4/2009, Beograd, 2009.

[23] Stojanović, S., Globalizacija i bezbednosne perspektive sistema, VIZ, Beograd, 2009.

[24] Simeunović, D., Terorizam - opšti deo, Biblioteka Crimen, Beograd, 2009, str. 7

[25] Schmidt P, A, Jongman J, A., Political Terrrorisim: A. New Guide to Aetros, Authors, Concepts, Data Bases, Theories and Literture, $\left(2^{\text {nd }}\right.$ ed) 1998.

[26] Sejdžmen, M., Terorističke mreže, Altera, Beograd, 2006, str. 9-11.

[27] Talijan M, M., Bezbednosni menadžment u suprotstavljanju terorizmu i borbu protivterorizma, Medija centar Odbrana, Beograd, 2012, str. 39.

[28] Trkulja, J., Aspekti globalizacije, Beogradska otvorena škola, Beograd, 2000.

[29] Held, D. , Demokratija i globalni poredak, Filip Višnjić, Beograd, 1997.

[30] Hantington, S, Sukob civilizacije i preoblikovanje svetskog poretka, CID, Podgorica, 1999.

[31] Hofman, B., Unutrašnji terorizam, Narodna knjiga, Beograd, 2000.

[32] Hadia Dajani: Shakeel and Ronald A.Meissir (eds), The Jihad and Its Times (Ann Arbor, Ml:Univrsity of Michigen Press, Rudolph Peters, Jihad in Classical and Modern Islam (Princeton: Markus, Wiene, 1996.

[33] Šikmn, M., Terorizam - aktuelni mogući oblici, Banja Luka, 2006.

[34] Sarah E Zabel, The Military Strategy of Global Jihad, Strategic Studies Institute, Uni fed States Army War College, 2007. htto://strategistudiesinstitute.army.mail/pubs/display.cfm?pubID=809

[35] Dictionary of Middle Ages ed Joseph R.Strayer (New York: Shareles Scribner s Sons, 1985) p. 483-489 http:// www.stategov/j/ct/rls/other/des/123085.htm

[36] Global trends 2015, http://www.cia.gov/news-information/press-releases-statements/pressrelease-archive-2000/12182000 html, 21.01.2018. 